\title{
X 帯民生 GaN HEMT を用いた搭載用固体電力増幅器の 動作条件による RF 特性と宇宙環境耐性評価*1 Evaluation of RF Characteristics Affected by Operational Conditions and Space Environmental Testing of X-band SSPA Using COTS GaN HEMT
}

\author{
小 林 雄 太吕・山本 善 一*2・川 崎 繁 男*2
}

Yuta KOBAYASHI, Zenichi YAMAMOTO and Shigeo KAWASAKI

\begin{abstract}
Key Words: Space Engineering, X-band COTS GaN HEMT, Space Communication, Solid State Power Amplifier, Space Environmental Testing
\end{abstract}
\begin{abstract}
GaN HEMT has been expected to satisfy requirements being used in space as amplifying devices of future high-efficiency onboard SSPAs due to its excellent properties such as robustness in a harsh environment, applicability to high frequency and high power operation. However, in X-band, the most important frequency band for space communication at this moment, evaluation of GaN HEMT to prove the space usage has not been conducted yet because ensuring a steady supply of X-band GaN HEMT devices is still difficult due to current collapse phenomena. Therefore, in this research, evaluation of RF characteristics affected by operational conditions and space environmental testing of X-band HPA using COTS GaN HEMT was conducted to secure the space usage.
\end{abstract}

\section{記 号 の 説 明}

$$
\begin{aligned}
V d: & \text { ドレイン電圧 }[\mathrm{V}] \\
V g: & \text { ゲート電圧 }[\mathrm{V}] \\
I d: & \text { ドレイン電流[A] } \\
I d s e t: & \text { ドレイン電流設定值 }[\mathrm{A}] \\
P A E: & \text { 電力付加効率 }[\%] \\
\eta: & \text { ドレイン効率 }[\%] \\
\text { Pin: } & \mathrm{RF} \text { 入力電力 }[\mathrm{dBm}] \\
\text { Pout }: & \mathrm{RF} \text { 出力電力 }[\mathrm{dBm}] \\
\text { Gain: } & \text { 利得 }[\mathrm{dB}] \\
\text { IM3: } & 3 \text { 次相互変調ひずみ }[\mathrm{dBc}] \\
\text { Psat }: & \text { 飽和出力電力 }[\mathrm{dBm}]
\end{aligned}
$$$$
\text { 1. は じめに }
$$

近年，宇宙機において X 帯 $(8 \mathrm{GHz}$ 帯) 通信システムが 担う役割はますます大きくなっている。これは高速大容量 通信，高精度軌道決定，科学ミッションの実施といった通 信機器に関わる要求がミッションの多様化と共に, 近地 球・深宇宙を問わず大きくなっていることに起因する ${ }^{1 \sim 3)}$. これらの要求は宇宙機からの通信品質を劣化させること無 く大電力高効率な通信を実現し，地上での $\mathrm{S} / \mathrm{N}$ (Signal-to-Noise ratio : 信号対雑音比) を改善するという共 通の要求に換言できる。しかし，宇宙機においては，サイ ズ・重量・消費電力といった厳しい制約が生じることに加 えて高い信頼性が求められることによって, 保守的な機器 を用いらざるを得ないためこの要求を満たすことは容易で

\footnotetext{
*1ㄷ2013 日本航空宇宙学会

平成 24 年 5 月 21 日原稿受付

*2 宇宙航空研究開発機構 宇宙科学研究所 通信・データ処理グループ
}

はない.一般に，宇宙機において通信システムは全消費電 力の約 $20 \%$ を占め, その中でも電力増幅器は約 $15 \%$ を占 めており, 電力増幅器の高効率化は宇宙通信のみならずバ ス機器全体における長年の課題の一つである。搭載系電力 増幅器は, TWTA（Traveling Wave Tube Amplifier : 進行波 管増幅器）とSSPA（Solid State Power Amplifier : 固体電力 増幅器）に大別され, 現状の宇宙機においてはX 帯の高出 力増幅器には TWTA が使用されている ${ }^{4)}$. これは TWTA の効率が 60 \%程度と高いことに起因するが，TWTA は SSPA と比べた場合, フットプリントの大型化, 短命化, 真空管利用による振動・衝撃耐性の劣化, 高電圧動作に伴 う真空移行中の放電リスクの増加等, 効率を除くあらゆる 面で宇宙機への適用には不利である。一方で，主に $20 \mathrm{~W}$ 未満の出力電力で用いられる SSPA は, 既存の機器では GaAs（Gallium Arsenide：ヒ化ガリウム）を増幅素子として 総合効率 $20 \%$ 程度となっている.つまり, SSPA で TWTA 並みの高効率化が実現できれば，これらの問題は全て解決 し結果的に宇宙機の通信性能の大幅な向上へとつなげられ る $^{5)}$.

加えて近年，地上の通信系においても急速に高効率な増 幅器の研究は進められており, 特にワイドバンドギャップ 素子を用いた高効率 SSPA の研究は GaN (Gallium Nitride : 窒化ガリウム)， $\mathrm{SiC}$ (Silicon Carbide：炭化ケイ素）デバ イス等を中心に様々な周波数で進められている. 第 1 表に これらの物性值の比較を示すが, $\mathrm{GaN}$ はワイドバンドギャ ップ, 高耐圧, 高熱伝導率等の特徵を保持し, 絶縁破壊電 圧と電子飽和速度の積である Johnson's figure of Merit (高周 波／ハイパワーデバイスに対しての性能指標）を比較する と, $\mathrm{GaN}>4 \mathrm{H}-\mathrm{SiC}>\mathrm{GaAs}$ となることからも高出力・高周 


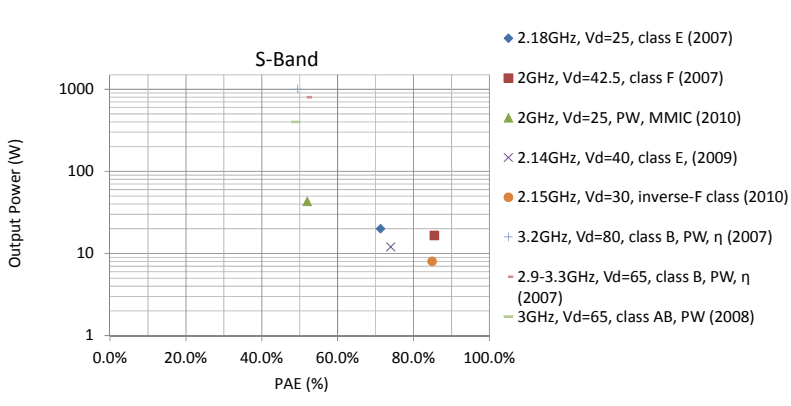

第 1 図 $\mathrm{S}$ 帯 $\mathrm{GaN}$ 研究成果

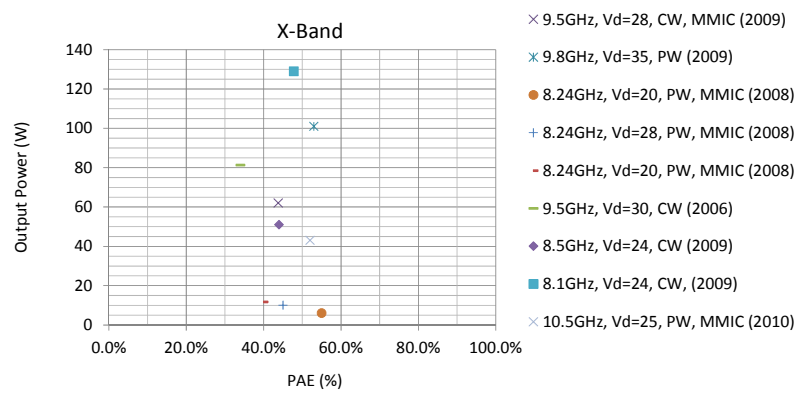

第 2 図 $\mathrm{X}$ 帯 $\mathrm{GaN}$ 研究成果

波増幅器に最適なデバイスと考えられる ${ }^{6)}$. 加えて, $500{ }^{\circ} \mathrm{C}$ 以上での動作確認結果や放射線照射に対する高いロバスト 性が L 帯（1 GHz 帯）・S 帯（2 GHz 帯）を中心に報告さ

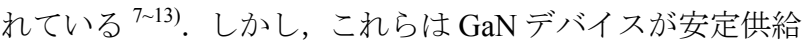
可能な低周波に限定したものとなっており，さらにはその 多くは DC (Direct Current: 直流) 特性の評価となっている. X 帯に関しては, NASA (National Aeronautics and Space Administration：アメリカ航空宇宙局）が DC と RF（Radio Frequency : 高周波) 特性に関する放射線試験結果を報告し ているが ${ }^{14)}$ ，この報告では， $\mathrm{GaN}$ デバイスは DCバイアス の夕の状態で放射線を照射され，照射前後の RF 特性を評 価しているため，放射線照射環境において長時間連続動作 させる宇宙用途を想定した RF 特性に関する放射線試験結 果は X 帯以上の GaN HEMT (High Electron Mobility Transistor : 高電子移動度トランジスタ）では報告されてい ないと言える.X 帯以上では高電圧動作時にトランジスタ のオン抵抗值が高くなってしまい, 結果的に損失が大きく なる現象である電流コラプスの問題が残存するため, X 帯 以上の GaN HEMT のこうした環境下での振舞いは特に未 知数であり, その特性評価は宇宙用途での使用には必須で ある。

ここで，第 1 図，第 2 図に $\mathrm{S}$ 帯，X 帯に関する近年の $\mathrm{GaN}$ を用いた増幅回路の研究成果として出力電力と効率 をまとめる ${ }^{15-27)}$. S 帯においては，F 級や逆 F 級といった 動作級の回路を用いることで，効率 80 \%以上といった研 究成果も出てきており，その出力レベルも $\mathrm{kW}$ クラスまで 達している。一方，X 帯については，MMIC（Monolithic Microwave Integrated Circuit：モノリシックマイクロ波集積 回路）の PW（Pulse Wave：パルス波形）動作で効率 $50 \%$ 以上の成果は見られるものの, CW (Continuous Wave : 連 続波）動作では効率は $40 \%$ 台に留まり, 出力レベルも数十
第 1 表 物性值比較

\begin{tabular}{lccc}
\hline & GaAs & 4H-SiC & GaN \\
\hline Band gap [eV] & 1.4 & 3.3 & 3.4 \\
\hline Relative permittivity & 12.8 & 10.0 & 9.5 \\
\hline Critical electric field $\left[10^{6} \mathrm{~V} / \mathrm{cm}\right]$ & 0.4 & 3.0 & 3.3 \\
\hline Saturation electron velocity $\left[10^{7} \mathrm{~cm} / \mathrm{s}\right]$ & 2.0 & 2.0 & 2.5 \\
\hline Thermal conductivity $[\mathrm{W} / \mathrm{cmK}]$ & 0.5 & 4.9 & 2.1 \\
\hline
\end{tabular}

第 2 表 GaN HEMT 仕様

\begin{tabular}{lcc}
\hline & F344 & TGI7785-25L \\
\hline Type & $\begin{array}{c}\text { Internal-matched GaN } \\
\text { HEMT on SiC (class AB) }\end{array}$ & $\begin{array}{c}\text { Internal-matched GaN } \\
\text { HEMT on SiC (class AB) }\end{array}$ \\
\hline Frequency & $5.8-8.5 \mathrm{GHz}$ & $7.7-8.5 \mathrm{GHz}$ \\
\hline Output power & Psat $>43.6 \mathrm{dBm}$ & $P$ sat $>44.5 \mathrm{dBm}$ \\
\hline Small signal gain & $>13.5 \mathrm{~dB}$ & $>12.0 \mathrm{~dB}$ \\
\hline Efficiency & $P A E>40 \%$ & $P A E>33 \%$ \\
\hline Drain voltage and current & $V d: 24 \mathrm{~V}$, Idset: $1.0 \mathrm{~A}$ & $V d: 24 \mathrm{~V}$, Idset: $1.4 \mathrm{~A}$ \\
\hline
\end{tabular}

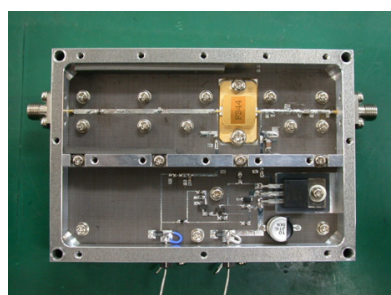

(a) F344

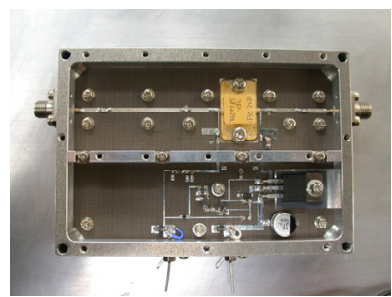

(b) TGI7785-25L

第3 図 SSPA BBM 外観

$\mathrm{W}$ クラスが主となり, 高出力・高効率に関して研究段階に あることが分かる。これは, 前述の通り X 帯以上の周波数 では，電流コラプスの問題が未解決なこともありデバイス の安定供給に至っていないことがその理由として挙げられ， X 帯以上においては COTS (Commercial Off-The-Shelf : 民 生品）の $\mathrm{GaN}$ デバイスも極端に少なく動作条件に関する報 告も少ない。

そこで，本研究では民生品の $20 \mathrm{~W}$ クラスの内部整合型 $\mathrm{X}$ 帯 GaN HEMT デバイスを用いて, 高出力・高効率な搭載 用 SSPA の実現に向けて，HPA（High Power Amplifier : 高 出力電力増幅器) の $\mathrm{CW}$ 動作時の動作条件 (ドレイン電圧, ゲート電圧，動作温度）の効率やひずみ特性といった通信 品質を含む RF 特性への影響の調査, ならびに, 熱真空試 験・放射線試験を通した而宇宙環境性能評価を実施し，X 帯の民生 GaN HEMT デバイスの搭載用 SSPA としての使用 に関して,技術的な知見を獲得することをその目的とする.

\section{2. 評価対象回路}

本研究では，X 帯民生 $\mathrm{GaN}$ デバイスとして，住友電気工 業株式会社の F344 と, 株式会社東芝の TGI7785-25L を用 いた．各々の仕様を第 2 表に示す。また，両デバイスを用 いて試作した SSPAの BBM (Bread Board Model : 機能試験 モデル）の外観を第 3 図に示す.

ここで，次章以降における動作条件の影響による宇宙環 境耐性の評価における比較対象結果として，各回路の定格 動作時の入出力特性とひずみ特性を第 4, 5 図に示す. 本測 定では，入出力特性を $8.50 \mathrm{GHz}$ で取得し，ひずみ特性は， $f_{l}=8.49 \mathrm{GHz}$ と $f_{2}=8.50 \mathrm{GHz}$ の 2 トーン入力時の IM3 $\left(3^{\text {rd }}\right.$ order Inter Modulation : 3 次相互変調ひずみ）を取得している. 
X 帯民生 GaN HEMT を用いた搭載用 SSPA の動作条件による RF 特性と宇宙環境而性評価（小林・山本・川崎）

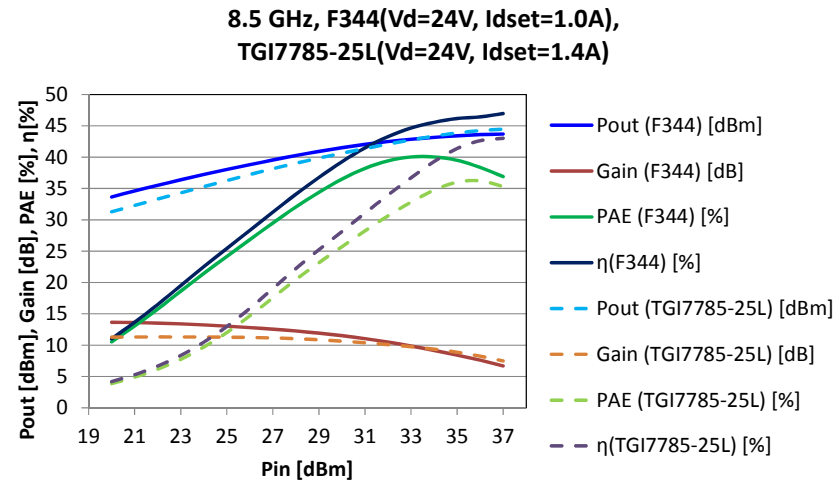

第4 図 定格動作時入出力特性（F344，TGI7785-25L）

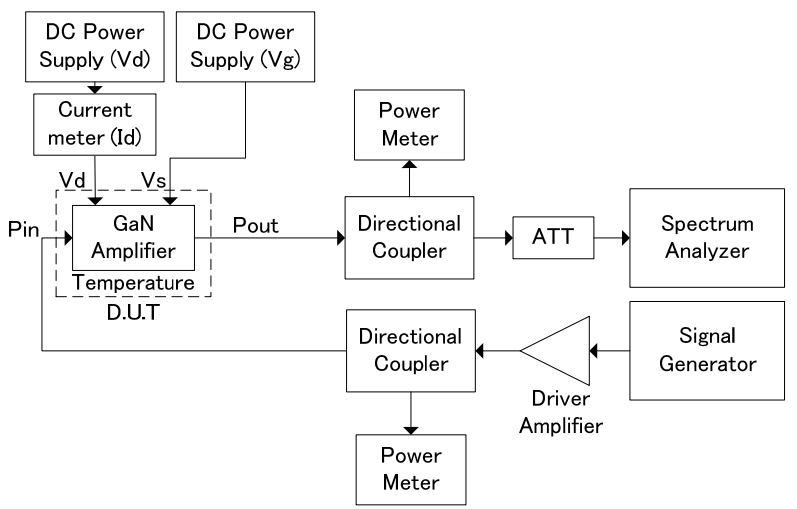

第 6 図 入出力特性測定系ブロックダイヤグラム

なお, 入出力特性における Gain (利得), PAE (Power Added Efficiency : 電力付加効率) , ク（ドレイン効率）は各々以 下の式(1)〜(3)より算出される.また, IM3 の結果では, 中 心周波数の低周波側に現れる $2 f_{1-} f_{2}$ を Low，高周波側に現 れる $2 f_{2}-f_{l}$ を High とそれぞれ表記している. 第 6 図に入出 力特性取得時の測定系ブロックダイヤグラムを, 第 7 図に ひずみ特性取得時の測定系ブロックダイヤグラムをそれぞ れ示す.

$$
\begin{aligned}
P A E & =\frac{\text { Pout }- \text { Pin }}{V d \cdot I d} \\
\text { Gain } & =\text { Pout }- \text { Pin } \\
\eta & =\frac{\text { Pout }}{V d \cdot I d}
\end{aligned}
$$

\section{3. 動作条件によるRF 特性・宇宙環境耐性評価}

3.1 評価項目 動作条件による評価としては, 主にバイ アス条件，周囲条件が存在する。本研究では，バイアス条 件としてドレイン電圧，ゲート電圧を定格值から変化させ た際の特性を評価し, 周囲条件として, 温度, 熱真空, 放 射線条件下での振る舞いを評価した。はじめにバイアス条 件のドレイン電圧に関しては, Fanning らの報告 ${ }^{28)}$ にある ように，ドレイン電圧の低下に伴う高効率化の傾向が見ら れた，次に，ゲート電圧によるバイアス条件の評価につい ては，今回使用しているデバイスがいずれも内部整合型で あることから，ゲートバイアス条件の変化が増幅回路の動 作級に影響を与えることはなく，低出力時のひずみ特性の

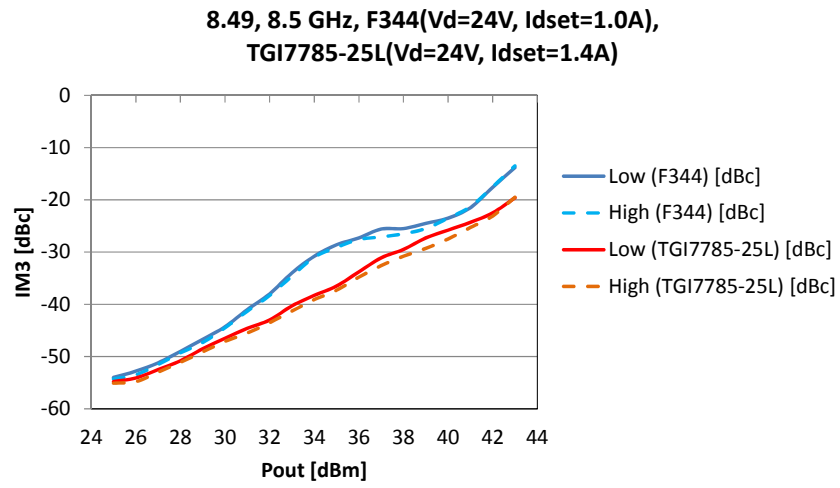

第 5 図＼cjkstart定格動作時ひずみ特性（F344，TGI7785-25L）

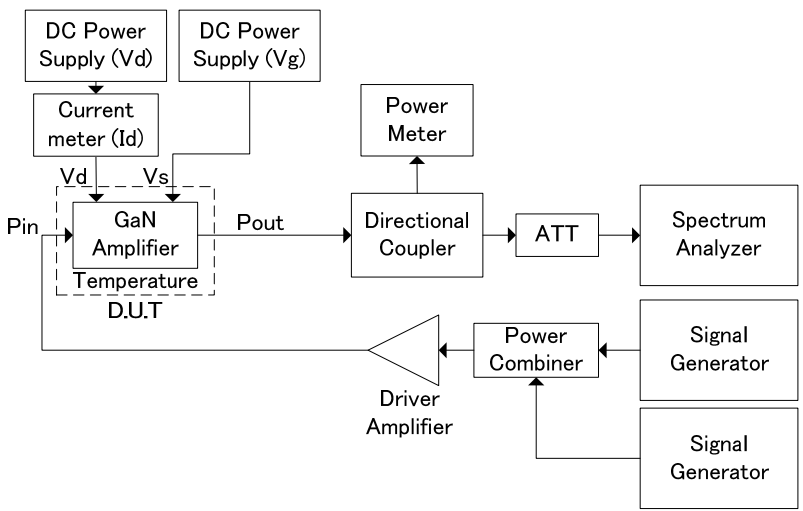

第 7 図 ひずみ特性測定系ブロックダイヤグラム

第 3 表 環境試験条件

\begin{tabular}{ll}
\hline \multicolumn{1}{c}{ Test } & \multicolumn{1}{c}{ Conditions } \\
\hline Temperature & $-5,25,55$ degree of Celsius \\
\hline Thermal vacuum & -20 to 60 degree of Celsius, $1 \mathrm{E}-4$ to $1 \mathrm{E}-3 \mathrm{~Pa}$ \\
\hline Radiation & $\begin{array}{l}{ }^{60} \mathrm{Co}, \text { Total Ionizing Dose: } 320 \mathrm{krad},(20 \mathrm{krad} / \mathrm{h}) \\
\text { Accelerated aging test: } 100 \text { degree of Celsius, } 168 \text { hours }\end{array}$ \\
\hline
\end{tabular}

改善のみが見られた。しかし，これらのバイアス条件の評 価では，今回評価に用いたデバイスが民生品であり，各メ 一カーの設計時の設計条件やパラメータが不明であること から， GaN デバイスの普遍的な振る舞いは議論できない. したがって，本論文では，主として周囲条件を動作条件と して扱い，その $\mathrm{RF}$ 特性への影響を調査することで $\mathrm{GaN} テ ゙$ バイスの宇宙環境耐性を評価する. 周囲条件に関しては,

Lee らによって, 動作温度を低温に保つことで効率の向上 が見込まれることが報告されている ${ }^{29)}$.しかし，これは大 気中のみの評価であり, 真空中の温度変化や大気中・真空 中それぞれの動作温度条件変化時の振る舞いは未評価であ る. 加えて, 放射線照射環境下での RF 連続動作について も, その評価は十分になされていないため, 本論文では, これらを総合的に評価し, GaN HEMT の宇宙環境而性につ いて知見を得ることを狙いとする. これらの環境試験条件 を第 3 表にまとめる.

3.2 温度試験 温度試験では, 動作温度を常温 $\left(25^{\circ} \mathrm{C}\right)$, 低温 $\left(-5{ }^{\circ} \mathrm{C}\right)$, 高温 $\left(55^{\circ} \mathrm{C}\right)$ と変化させた際の $\mathrm{RF}$ 特性 を取得した。試験は，第 8 図のブロックダイヤグラムに示 
$8.5 \mathrm{GHz}, \mathrm{F} 344(\mathrm{Vd}=24 \mathrm{~V}$, Idset $=1.0 \mathrm{~A})$

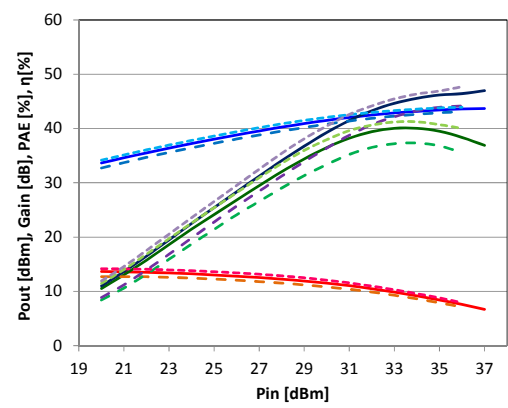

-Pout $\left(\mathrm{F} 344,25^{\circ} \mathrm{C}\right)[\mathrm{dBm}]$

—Gain $\left(\mathrm{F} 344,25^{\circ} \mathrm{C}\right)[\mathrm{dB}]$

- PAE $\left(\mathrm{F} 344,25^{\circ} \mathrm{C}\right)[\%]$

- $\left(\mathrm{F} 344,25^{\circ} \mathrm{C}\right)[\%]$

- - Pout $\left(\mathrm{F} 344,55^{\circ} \mathrm{C}\right)[\mathrm{dBm}]$

- - Gain $\left(\mathrm{F} 344,55^{\circ} \mathrm{C}\right)[\mathrm{dB}]$

- $\operatorname{PAE}\left(\mathrm{F} 344,55^{\circ} \mathrm{C}\right)[\%]$

- - $\eta\left(F 344,55^{\circ} \mathrm{C}\right)[\%]$

-.- Pout $\left(\mathrm{F} 344,-5^{\circ} \mathrm{C}\right)[\mathrm{dBm}]$

--- Gain $\left(F 344,-5^{\circ} \mathrm{C}\right)[\mathrm{dB}]$

-- PAE $\left(\mathrm{F} 344,-5^{\circ} \mathrm{C}\right)[\%]$

$--\eta\left(F 344,-5^{\circ} \mathrm{C}\right)[\%]$

第 9 図 F344 入出力特性（温度試験）

$8.49,8.5 \mathrm{GHz}, \mathrm{F} 344(\mathrm{Vd}=24 \mathrm{~V}$, Idset=1.0A)

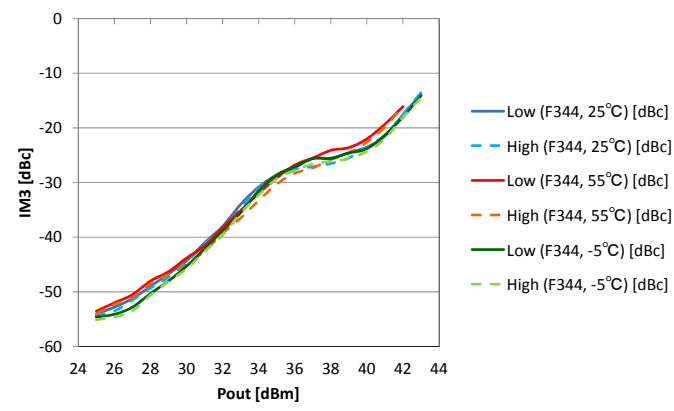

第 10 図 F344 ひずみ特性（温度試験）

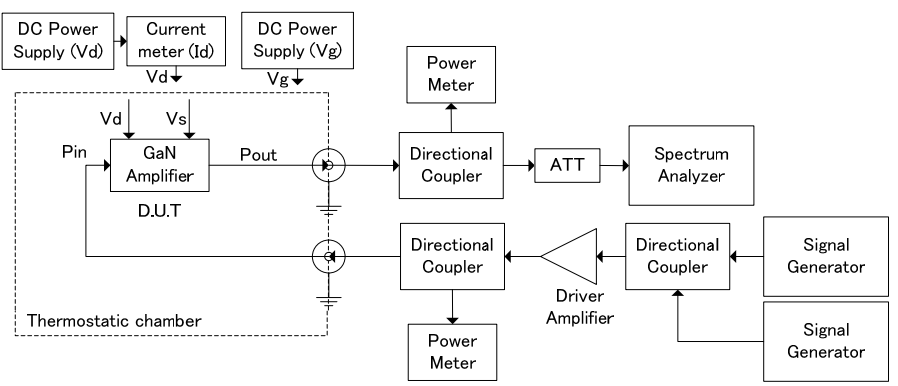

第 8 図 温度試験測定系ブロックダイヤグラム

す構成で実施され, 各増幅器は, 恒温槽内でファン付のヒ ートシンクに設置された. 低温, 常温, 高温, 各温度条件 時の増幅器のケース温度は, $\mathrm{F} 344$ で $0.2{ }^{\circ} \mathrm{C}, 29.8{ }^{\circ} \mathrm{C}$, $59.8{ }^{\circ} \mathrm{C}$ の定常值を示し, TGI7785-25L では $1.1{ }^{\circ} \mathrm{C}, 30.3{ }^{\circ} \mathrm{C}$, $61.3{ }^{\circ} \mathrm{C}$ それぞれ示した.第 9 図, 第 10 図にそれぞれ F344 の入出力特性とひずみ特性を示し，第 11 図，第 12 図に TGI7785-25L の同様の結果を示す. 第 9 図, 第 11 図より, 常温動作時を基準とした場合，低温動作において，飽和出 力電力, 利得が向上し, $43 \mathrm{dBm}$ 出力時で比較した場合,

F344 で PAE が $1.0 \%$ 上昇し, TGI7785-25L においても $2.2 \%$ $P A E$ が上昇した。一方で，高温動作においては，飽和出力 電力, 利得が劣化し, $43 \mathrm{dBm}$ 出力時に常温動作と比較した 場合, F344 でPAE が $3.9 \%$ 低下し, TGI7785-25L において, $2.4 \%$ 低下した。これらは, 低温動作と比較して, 高温動作 では, 温度が高い分, 電子の運動度が増し, 結果的にドレ イン電流值が増加していることに起因すると考えられる. 今回は，排熱が十分に行えていたことに加えて，F344， TGI7785-25Lいずれも GaN on SiC のデバイスとなっている
$8.5 \mathrm{GHz}, \mathrm{TG} 17785-25 \mathrm{~L}(\mathrm{Vd}=24 \mathrm{~V}$, Idset=1.4A)

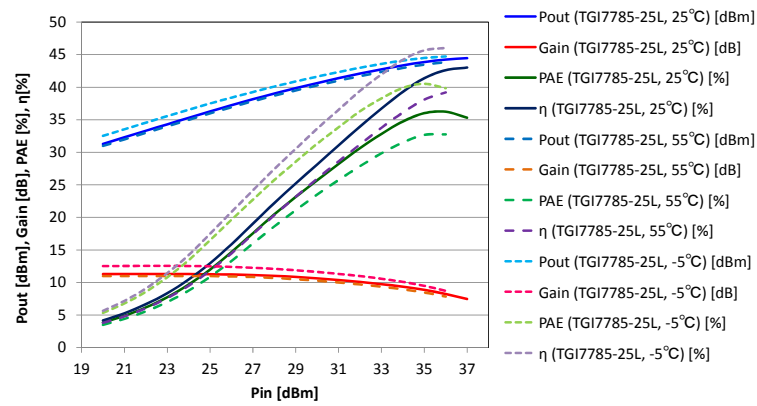

第 11 図 TGI7785-25L 入出力特性（温度試験）

$8.49,8.5 \mathrm{GHz}, \mathrm{TG} \mid 7785-25 \mathrm{~L}(\mathrm{Vd}=24 \mathrm{~V}$, Idset=1.4A)

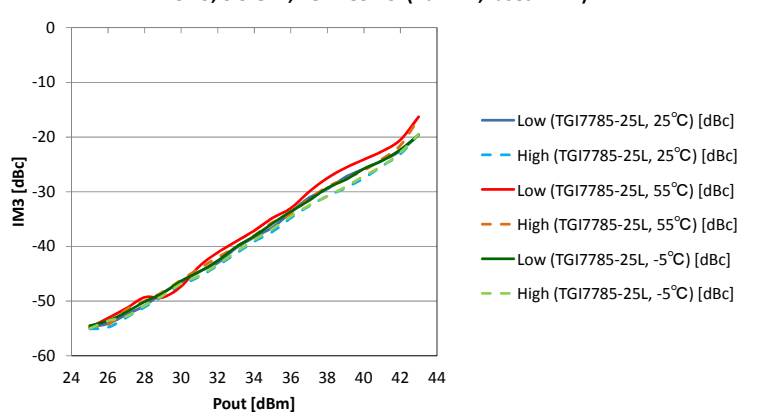

第 12 図 TGI7785-25L ひずみ特性（温度試験）

ことから， $\mathrm{SiC}$ の高い熱伝導率により，20 W の高出力動作 においても，温度試験による影響は軽微な結果となったと 考えられる.

次に，第 10 図，第 12 図より，動作温度に対するひずみ 特性の変化は，F344，TGI7785-25L いずれにおいても，ほ とんど見られなかった。つまり，同一バイアス条件下での 温度に関する周囲条件の変化は，ひずみ特性には大きく影 響はしないと言える。

3.3 熱真空試験 熱真空試験としては, 搭載機器に要 求される動作維持温度に基づく温度条件と高真空領域の真 空度の条件を付与した. F344, TGI7785-25L の増幅回路は, $300 * 400 * 10 \mathrm{~mm}$ のアルミ板の治具を介して, 熱真空試験チ ヤンバの底板に固定され，底板の温度を制御する形で，試 験を実施した. 第 13 図に試験系のブロックダイヤグラムを 示寸. 第 3 表に示寸通り, 低温最悪条件として $-20^{\circ} \mathrm{C}$, 高温 最悪条件として $60^{\circ} \mathrm{C} の$ 条件を与え, 入出力特性ならびに, 連続動作時の増幅器ケース温度の特性をそれぞれの増幅回 路について個別に取得した. F344 の常温真空時の結果と比 較した入出力特性, 低温最悪, 高温最悪条件時の連続動作 における温度特性をそれぞれ第 14 図，第 15 図に示す。ま た, 第 16 図, 第 17 図に TGI7785-25L の同様の結果を示す. 第 14 図, 第 16 図より，常温真空時を基準とした場合，低 温真空動作において, 飽和出力電力, 利得が向上し, 最大 効率時で比較した場合, F344 で PAE が $6.5 \%$ 上昇し, TGI7785-25L においても $2.0 \%$ 上昇した. 一方で, 高温真空 動作においては, 飽和出力電力, 利得が劣化し, 最大効率 を常温真空動作時と比較した場合, F344 で PAE が $3.4 \%$ 低 


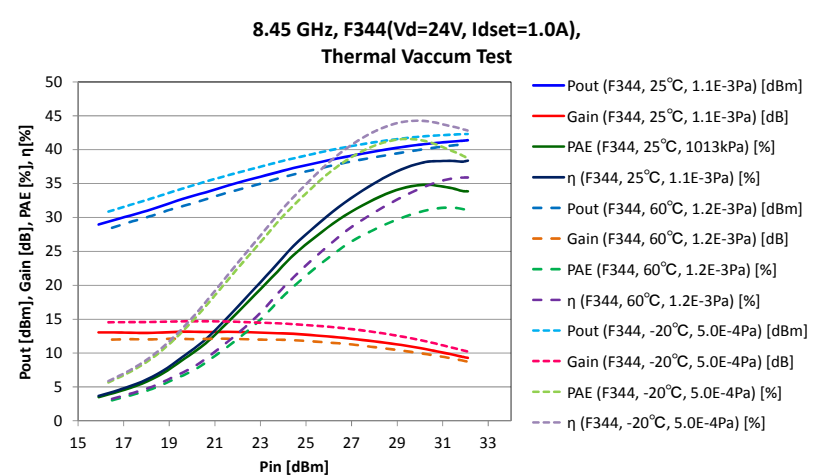

第 14 図 F344 入出力特性（熱真空試験）

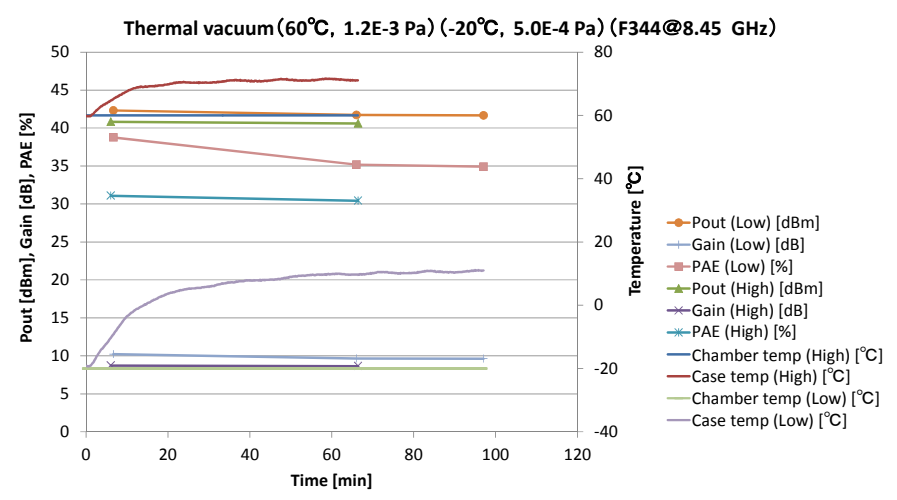

第 15 図 F344 熱真空試験時温度特性

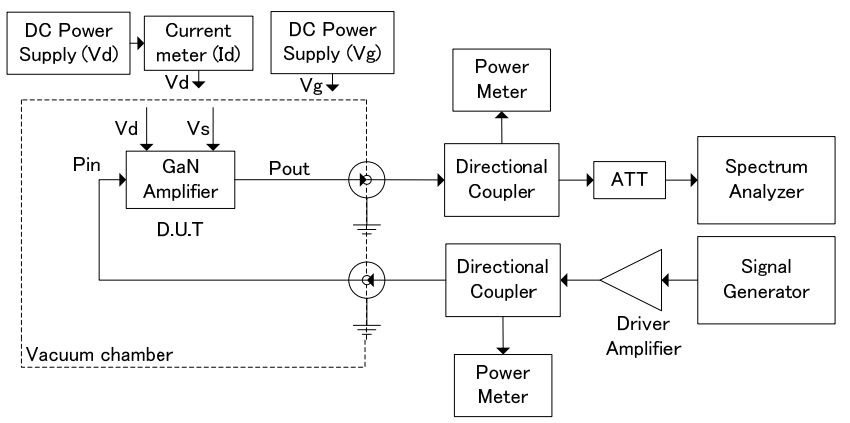

第 13 図 熱真空試験測定系ブロックダイヤグラム

下し，TGI7785-25L において，1.7\%低下した。これまでに 示した温度試験・熱真空試験時の常温時と比較した場合の $P A E$ の変化を第 4 表にまとめる。 第 4 表より, 周囲温度 の変化に関しては，大気中・真空中いずれにおいても低温 側での効率向上，高温側での効率劣化の傾向が共通して見 て取れる。また, 温度試験と比較した場合, 熱真空試験で は放電のリスクについてもその確認が可能となるが，今回 の測定ではいずれの動作においても，GaAs と比べた際に 高電圧で動作させる観点から GaN において懸念される真 空動作での放電は見られず，安定した動作が確認された。

次に，第 15 図，第 17 図より，F344，TGI7785-25Lいず れも動作開始後, 約 1 時間で温度特性が定常化しているこ とが分かる. その間の出力電力や利得, $P A E$ に関しても, 大きな劣化は見られない. しかし一方で，低温真空側での 温度特性の安定化にはいずれのデバイスも高温真空側より も時間を要する傾向が見られた。これは，熱真空試験にお

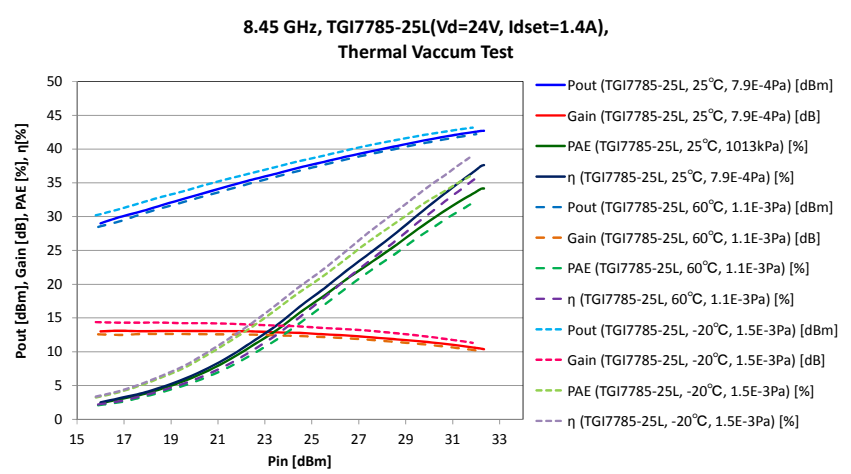

第 16 図 TGI7785-25L 入出力特性（熱真空試験）

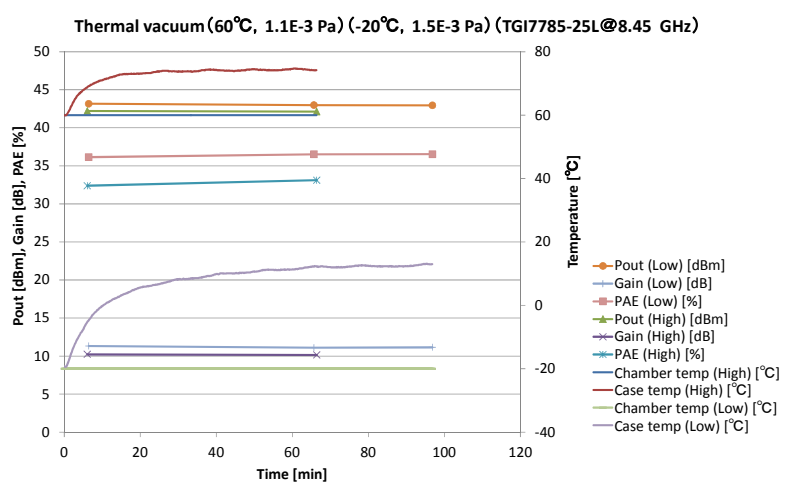

第 17 図 TGI7785-25L 熱真空試験時温度特性

第 4 表 温度試験・熱真空試験時の RF 特性まとめ

\begin{tabular}{|c|c|c|c|c|}
\hline & \multicolumn{2}{|c|}{ F344 } & \multicolumn{2}{|c|}{ TGI7785-25L } \\
\hline & \multicolumn{2}{|c|}{$\triangle P A E[\%]$} & \multicolumn{2}{|c|}{$\triangle P A E[\%]$} \\
\hline & Temperature & $\begin{array}{l}\text { Thermal } \\
\text { vacuum }\end{array}$ & Temperature & $\begin{array}{l}\text { Thermal } \\
\text { vacuum }\end{array}$ \\
\hline Low & $+1.0 \%$ & $+6.5 \%$ & $+2.2 \%$ & $+2.0 \%$ \\
\hline High & $-3.9 \%$ & $-3.4 \%$ & $-2.4 \%$ & $-1.7 \%$ \\
\hline
\end{tabular}

けるアルミ板の治具への熱伝導のみの排熱能力が，ヒート シンクおよびファンを利用した温度試験における対流や熱 伝導を含む排熱能力よりも悪かったことが原因と考えられ る.この排熱能力の不足から外部温度が低温状態であって も，ケース温度は上昇を続け，電子移動度が増すことによ ってドレイン電流值が増加し，結果的に効率が低下し，更 に熱が放出されるという悪循環が続いたと考えられる.

以上から今回の評価においては, 対流, 熱伝導等の熱の 伝達方法に関わらず，GaN デバイス自体の動作温度が周囲 温度の変化に追随して変化する環境下であれば, $\mathrm{GaN}$ デバ イスは，真空の影響を受けず，大気中と同等の振る舞いを 行うことが示された。したがって，排熱の経路をしっかり と確保することが搭載用を考える場合，非常に重要になる と言える.

3.4 放射線試験 放射線試験に関しては, GaN のワイ ドバンドギャップという特性が, 従来の GaAs と比較して もシングルイベントに対して強い耐性を持つことから， ${ }^{60} \mathrm{Co}$ を用いたトータルドーズの条件を与えている。総照射 線量として定めた $320 \mathrm{krad}$ は, 現行の衛星プロジェクトに おけるアルミハニカム構造（アルミ厚 $0.6 \mathrm{~mm}$ ）を考慮した 


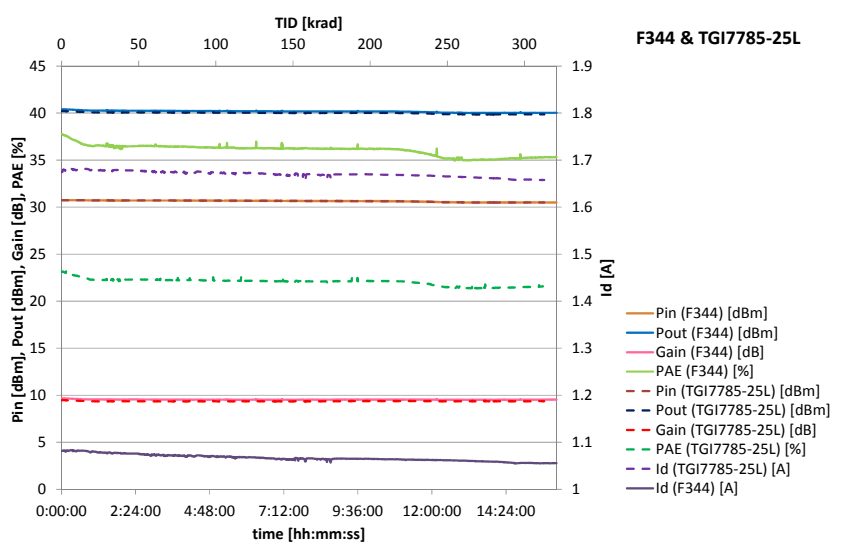

第 19 図 放射線試験測定結果

$8.45 \mathrm{GHz}, \mathrm{F344}(\mathrm{Vd}=24 \mathrm{~V}$, Idset=1.0A)

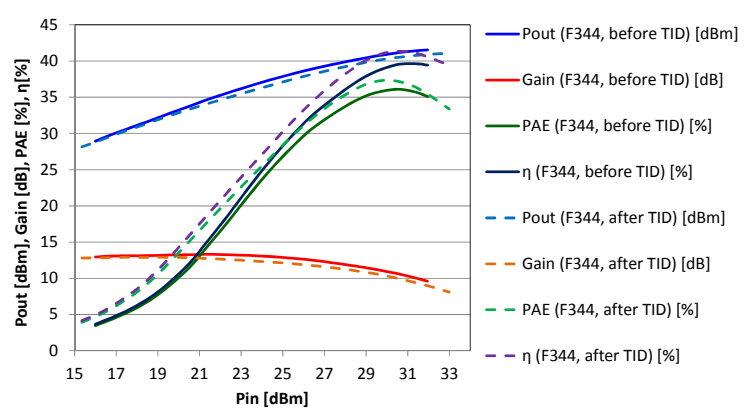

第 21 図 F344 入出力特性（放射線試験前後）

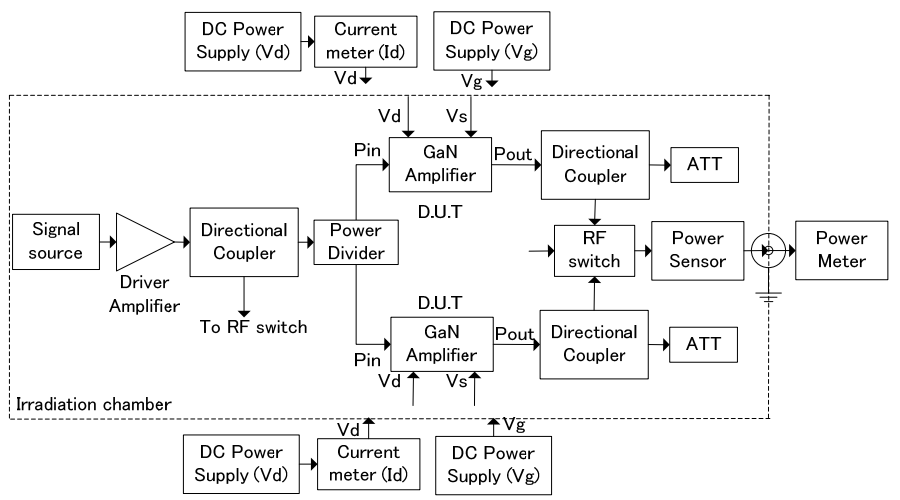

第 18 図放射線試験測定系ブロックダイヤグラム

際に，バス機器が置かれる環境において，太陽活動等を最 悪条件で考えた場合に, 深宇宙探査ミッションで約 10 年, 地球周回低軌道衛星で 100 年以上に相当する照射量である 30)。これらは，各軌道におけるミッション期間に関する一 般的な要求を十分に満足する值である。なお，照射率は， standard rate とし ${ }^{31)}$, 放射線試験, 及び照射後の加速エージ ング試験の手順等は, ESA (European Space Agency : 欧州 宇宙機関）が定める規定に則っている ${ }^{31)}$ 。放射線試験時の 測定系ブロックダイヤグラムを第 18 図に示す。ここで, 第 18 図において, 照射室内に設置されている試験対象の増幅 回路以外は，鉿のブロックで覆うことで放射線の影響を最 小限に抑えている。試験は，独立行政法人日本原子力研究 開発機構高崎量子応用研究所内の食品照射棟にて実施した. 前述の通り，ミッション期間を考慮した放射線試験におい

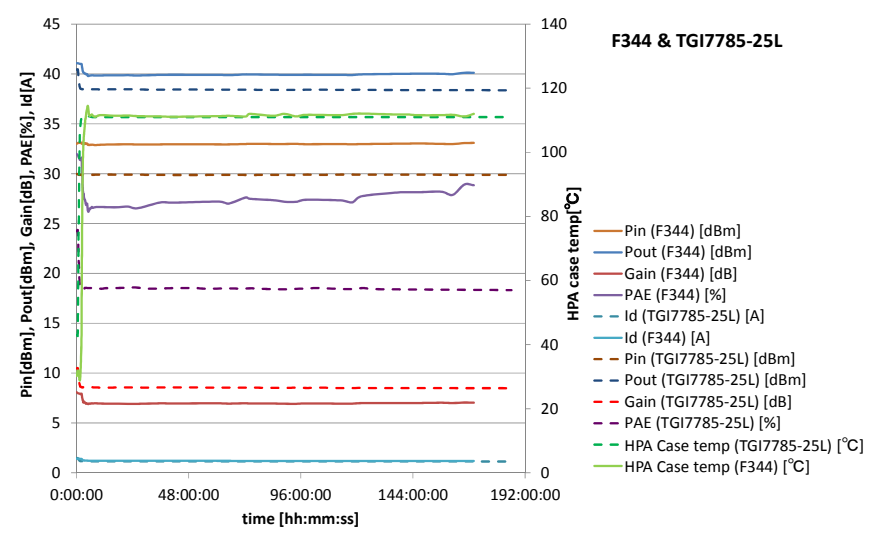

第 20 図 加速エージング試験測定結果

$8.45 \mathrm{GHz}, \mathrm{TG} 17785-25 \mathrm{~L}(\mathrm{Vd}=24 \mathrm{~V}$, Idset=1.4A)

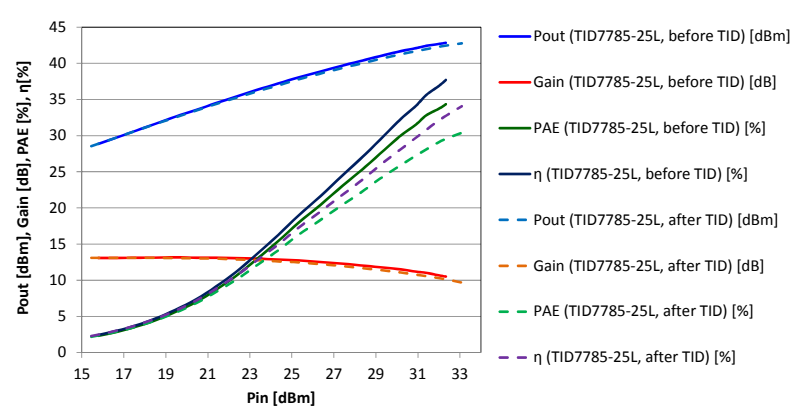

第 22 図 TGI7785-25L 入出力特性（放射線試験前後）

第 5 表 放射線試験開始時と終了時の各測定データ

\begin{tabular}{ccccccccc}
\hline & \multicolumn{4}{c}{ F344 } & \multicolumn{5}{c}{ TGI7785-25L } \\
\cline { 2 - 9 } & PAE & Pout & Pin & Gain & PAE & Pout & Pin & Gain \\
\hline Radiation & 37.8 & 40.4 & 30.7 & $\begin{array}{c}9.7 \\
\text { start } \\
\text { 0:00:00 }\end{array}$ & $\begin{array}{c}23.1 \\
\%\end{array}$ & $\begin{array}{c}40.2 \\
\mathrm{dBm}\end{array}$ & $\begin{array}{c}30.7 \\
\mathrm{dBm}\end{array}$ & $\begin{array}{c}9.5 \\
\mathrm{~dB}\end{array}$ \\
\hline $\begin{array}{c}\text { Radiation } \\
\text { finish }\end{array}$ & $\begin{array}{c}35.3 \\
\%\end{array}$ & $\begin{array}{c}40.0 \\
\mathrm{dBm}\end{array}$ & $\begin{array}{c}30.5 \\
\mathrm{dBm}\end{array}$ & $\begin{array}{c}9.5 \\
\mathrm{~dB}\end{array}$ & $\begin{array}{c}21.6 \\
\%\end{array}$ & $\begin{array}{c}39.9 \\
\mathrm{dBm}\end{array}$ & $\begin{array}{c}30.5 \\
\mathrm{dBm}\end{array}$ & $\begin{array}{c}9.4 \\
\mathrm{~dB}\end{array}$ \\
\hline
\end{tabular}

て, RF 出力を連続動作として評価した結果は, これまで報 告されていないため, 本試験では 16 時間の放射線試験中, 各増幅回路はヒートシンクに固定され，常に飽和出力近辺 で連続動作させた．放射線試験後は，加速エージング試験 として, $100{ }^{\circ} \mathrm{C}$ 恒温槽で一週間, 飽和出力近辺での連続 動作を行った。第 19 図に放射線試験照射中の F344, TGI7785-25L の入出力特性の時間変化を示す.一方, 第 20 図に加速エージング試験中の F344, TGI7785-25L の入出力 特性の時間変化を示す. 最後に, 放射線試験前と加速エー ジング試験後の F344, TGI7785-25L 各々の入出力特性の変 化を第 21 図, 第 22 図に示す. はじめに第 19 図より, F344, TGI7785-25Lいずれも $320 \mathrm{krad}$ の放射線照射を通して, $P A E$ の劣化が見られ，最終的に放射線照射終了時点で，開始時 よりも $2.5 \%, 1.5 \%$ 各々減少した. また, 同図より, 照射 開始直後や照射開始 11 時閒後近辺に, いずれの増幅回路も $P A E$ の劣化が著しい領域が存在する.しかし, ドレイン電 流の時間プロットを見ると, F344, TGI7785-25L 各々の電 流值は $320 \mathrm{krad}$ の照射で計 $25 \mathrm{~mA}, 22 \mathrm{~mA}$ の減少を照射開 始から一定の傾きで示しているため, F344, TGI7785-25L の各回路において, これらの時点で極端な劣化が見られた 
X 帯民生 GaN HEMT を用いた搭載用 SSPA の動作条件による RF 特性と宇宙環境而性評価（小林・山本・川崎）

とは言い難い.ここで，F344，TGI7785-25L 各々の照射開 始時と照射終了時の各測定值を第 5 表にまとめる. 第 5 表 から分かるように，各回路の効率の劣化は，入力電力の低 下が最大の要因となっており，共通のドライバーアンプか ら RF 電力を供給していることや，両回路ともに利得の低 下が少ないことから，放射線試験中の特性劣化は，照射室 内に設置したドライバーアンプの劣化による影響が最も支 配的であると考えられる.

次に，第 20 図より，加速エージング試験では，試験開始 から恒温槽の温度が安定するまでの約 4 時間, F344, TGI7785-25L いずれもその特性が劣化しており，PAEで見 た場合，加速エージング試験開始時と比較して，4 時間後 の時点で各々 $5.1 \%, 5.7 \%$ 低下した。 しかし，恒温槽の安 定後は約 164 時間の連続動作中, PAE の変動は, F344 で試 験開始時と比較した場合，全て 2.8〜 5.8\%低下の範囲に収 まり，TGI7785-25L では同様に全て 5.1〜 5.3\%低下の範囲 に収まる結果となった。したがって，加速エージング試験 中の $100{ }^{\circ} \mathrm{C}$ で安定動作が確認されたと言える.

最後に，第 21 図，第 22 図より，放射線試験，及び加速 エージング試験を終えた F344，TGI7785-25L の入出力特性 を放射線試験開始前のものと比べると，F344 では，非線形 動作領域における利得の低下に伴い, 出力が $0.5 \mathrm{dBm}$ 程度 低下している。 TGI7785-25L においても，同様に非線形動 作領域において, 利得の低下が見られ, 出力が $0.5 \sim 1.0 \mathrm{dBm}$ 低下し, それに伴って, $P A E$ は最大で約 $3 \%$ 劣化している. なお，非線形動作領域において，この傾向が大きく見えて いるのは，放射線試験の影響で，特に飽和領域における利 得が低下した結果，非線形動作領域での同じ入力レベルに 対する出力レベルの低下が見えていること, 並びに $\mathrm{GaN}$ は GaAs と比較した際に耐圧や熱伝導率の優位さから, 利得 が低下してもドレイン電流を増やすことで出力レベルが低 下しにくい特徵を持つこと等が，その理由として考えられ る.

\section{4. まと め}

本研究では，国産の内部整合型 $\mathrm{X}$ 帯民生 $\mathrm{GaN}$ デバイス （F344，TGI7785-25L）を用いて，動作条件による RF 特性 への影響として, 温度試験・熱真空試験・放射線試験を通 した宇宙環境而性の評価を実施した。動作温度変化に関し ては，大気中・真空中いずれの評価も実施し，両デバイス において，低温側で $1.0 \sim 6.5 \%$ 程度の効率向上，高温側で 1.7〜3.9\%程度の効率劣化が見られた。 また，いずれの温. 度条件においても，真空による放電は確認されなかった。 一方，宇宙空間での連続動作を考慮し，これまで実施され てこなかった RF 出力中の放射線試験を実施し, 全照射時 間における特性データを取得し，放射線試験前後で最大 $3 \%$ 程度の効率劣化が確認された。 国産の民生 GaN HEMT を用いたこれらのデータはこれまで報告されておらず，ア プリケーションの要求に依存する部分は残るものの，民生 品であっても十分に宇宙用途としての仕様を満たす可能性 を示したと言える。これらによって，宇宙通信で主要な周
波数帯であるX 帯通信システムへの GaN HEMT デバイス を用いた高出力・高効率な搭載用 SSPA の実現に向けた大 きな知見が得られた。

増幅回路試作に関して，多大なるご支援を頂いたアイ電 子株式会社伊東正展氏，山下與慶氏，重田修氏，布村仁志 氏にこの場をお借りして，心から感謝の意を述べさせて頂 きます。また，放射線試験時の施設利用に関してご協力頂 きました独立行政法人日本原子力研究開発機構高崎量子応 用研究所春山保幸氏，野上大地氏，山縣諒平氏にも深く謝 意を示します. 最後に, 各実験において, 協力頂いた JAXA 粟野稿太氏，冨木淳史氏，阿部まみ氏，戸田知朗氏に謝意 を示し，本論文の謝辞とさせて頂きます.

\section{参 考 文 献}

1) Sanchez, S., Lopez, E., Oster, J., Midan, E., Venditti, P., Sigismondi, R. and Martinez, M.: High Data Rate Multi-mission X-band Transmission Assembly for Earth Observation Satellites, $5^{\text {th }}$ ESA International Workshop on Tracking, Telemetry and Command Systems for Space Applications, Noordwijk, Netherlands, Sep. 2010.

2) Mercolino, M., Border, J. S., Madde, R. and Takeuchi, H.: Delta-DOR interoperability and gross-support between ESA, JPL, and JAXA, $5^{\text {th }}$ ESA International Workshop on Tracking, Telemetry and Command Systems for Space Applications, Noordwijk, Netherlands, Sep. 2010.

3) Toda, T., Tomiki, A. and Imamura, T.: Phase noise reduction of X-band transponder for radio science of AKATSUKI, $5^{\text {th }}$ ESA International Workshop on Tracking, Telemetry and Command Systems for Space Applications, Noordwijk, Netherlands, Sep. 2010.

4) Toda, T., Nagae, T., Kamata, Y., Ishii, N. and Nakamura, M.: The newly developed deep space communication instruments for JAXA venus mission, Proceedings of $60^{\text {th }}$ International Astronautical Congress, Daejeon, Korea, Oct. 2009

5) 小林雄太, 粟野稿太, 野地紘史, 冨木淳史, 川崎繁男: GaN を用 いた搭載用固体電力増幅器の研究, 第 12 回宇宙科学シンポジウム, 相模原，日本，2012 年 1 月.

6) 財団法人新機能素子研究開発協会 : GaN パワー結晶材料・デバイ スに関する技術調査報告書， 2007 年 3 月.

7) Maier, D., Alomari, M., Grandjean, N., Carlin, J. F., di Forte-Poisson, M. A., Dua, C., Chuvilin, A., Troadec, D., Gaquiere, C., Kaiser, U., Delage, S. L. and Kohn, E.: Testing the Temperature Limits of GaN-based HEMT Devices, IEEE Transactions on Device and Materials Reliability, 10, 4( 2010), pp. 427-436.

8) Mengistu, E. S.: Large-signal Modeling of GaN HEMTs for Linear Power Amplifier Design, Kassl University press, Hessen, 2007.

9) Harris, R. D., Scheick, L. Z., Hoffman, J. P., Thrivikraman, T., Gim, Y. and Miyahira, T.: Radiation Characterization of Commercial GaN Devices, Radiation Effects Data Workshop, Nashville, USA, Mar. 2011.

10) Nedelcescu, A. I., Carlone, C., Houdayer, A., von Bardeleben, H. J., Cantin, J. L. and Raymond, S.: Radiation Hardness of Gallium Nitride, IEEE Transactions on Nuclear Science, 49, 6(2002), pp. 2733-2738.

11) Hu, X., Karmarkar, A. P., Jun, B., Fleetwood, D. M., Schrimpf, R. D., Geil, R. D., Weller, R. A., White, B. D., Bataiev, M., Brillson, L. J. and Mishra, U. K.: Proton-irradiation Effects on AlGaN/AlN/GaN High Electron Mobility Transistors, IEEE Transactions on Nuclear Science, 50, 6(2003), pp. 1791-1796.

12) Sellin, P. J. and Vaitkus, J.: New Materials for Radiation Hard Semiconductor Detectors, Nucl. Instrum. Methods Phys. Res., 557(2006) pp. 479-489.

13) Aktas, O., Kuliev, A., Kumar, V., Schwindt, R., Toshkov, S., Costescu, 


\section{航空宇宙技術＼cjkstart第 12 巻（2013 年）}

D., Stubbins, J. and Adesida, I.: ${ }^{60}$ Co Gamma Radiation Effects on DC, RF, and Pulsed I-V Characteristics of AlGaN/GaN HEMTs, Sol. -St. Elect., 48(2004), pp. 471-475.

14) Simons, R. N. and Oldham, T. R.: Total Dose Test Report for GaN $\mathrm{X}$-band Amplifier, NASA Electronic Parts and Packaging Program, https://nepp.nasa.gov/

15) Lee, Y. S. and Jeong, Y. H.: A High-Efficiency Class-E GaN HEMT Power Amplifier for WCDMA Applications, IEEE Microwave and Wireless Components Letter, 17, 8(2007), pp. 622-624.

16) Schmelzer, D. and Long, S. I.: A GaN HEMT Class F Amplifier at 2 $\mathrm{GHz}$ with $>80 \%$ PAE, IEEE Journal of Solid-State Circuit, 42, 10(2007), pp. 2130-2136.

17) Piotrwicz, S., Ouarch, Z., Chartier, E., Aubry, R., Callet, G., Floriot, D., Jacquet, J. C., Jardel, O., Morvan, E., Reveyrand, T., Sarazin, N. and Delage, S. L.: 43W, 52\% PAE X-Band AlGaN/GaN HEMTs MMIC Amplifiers, Microwave Symposium Digest, 2010 IEEE MTT-S International, Anaheim, USA, May 2010.

18) van der Heijden, M. P., Acar, M. and JVromans, J. S.: A Compact 12-Watt High-efficiency 2.1-2.7 GHz Class-E GaN HEMT Power Amplifier for Base Stations, Microwave Symposium Digest, 2009 IEEE MTT-S International, Boston, USA, June 2009.

19) Saad, P., Fager, C., Cao, H., Zirath, H. and Andersson, K.: Design of a Highly Efficient 2-4-GHz Octave Bandwidth GaN-HEMT Power Amplifier, IEEE Transaction of Microwave and Techniques, 58, 7(2010), pp. $1677-1685$.

20) Roberg, M., Hoversten, J. and Popovic, Z.: GaN HEMT PA with Over 84\% Power Added Efficiency, IEEE Electronics Letters, 46, 23(2010), pp. 1553-1554.

21) Mitani, E., Aojima, M. and Sano, S.: A kW-class AlGaN/GaN HEMT Pallet Amplifier for S-band High Power Application, Microwave Integrated Circuit Conference, EuMIC 2007, Munich, Deutschland, Oct. 2007.

22) Krishnamurthy, K., Martin, J., Landberg, B., Vetury, R. and Poulton, M. J.: Wideband $400 \mathrm{~W}$ Pulsed Power GaN HEMT Amplifiers, Microwave Symposium Digest, 2008 IEEE MTT-S International, Atlanta, USA, June 2008 .
23) Yamashita, Y., Nakada, T., Kumamoto, T., Suzuki, R. and Tanabe, M.: X-Band GaN HEMT Advanced Power Amplifier Unit for Compact Active Phased Array Antennas, ICROS-SICE International Joint Conference 2009, Fukuoka, Japan, Aug. 2009.

24) Shigematsu, H., Inoue, Y., Akasegawa, A., Yamada, M., Masuda, S., Kamada, Y., Yamada, A., Kanamura, M., Ohki, T., Makiyama, K., Okamoto, N., Imanishi, K., Kikkawam, T., Joshin, K. and Hara, N.: C-band 340-W and X-band 100-W GaN Power Amplifiers with Over 50-\% PAE, Microwave Symposium Digest, 2009 IEEE MTT-S International, Boston, USA, June 2009.

25) Quay, R., van Raay, F., Kuhn, J., Kiefer, R., Waltereit, P., Zorcic, M., Musser, M., Bronner, W., Dammann, M., Eggebert, M. S., Schlechtweg, M., Mikulla, M., Ambacher, O., Thorpe, J., Riepe, K., van Rijs, F., Saad, M., Harm, L. and Rodle, T.: Efficient AlGaN/GaN HEMT Power Amplifiers, Microwave Integrated Circuit Conference, EuMIC 2008, Amsterdam, Netherland, Oct. 2008

26) Takagi, K., Masuda, K., Kashiwabara, Y., Sakurai, H., Matsushita, K., Takatsuka, S., Kawasaki, H., Takada, Y. and Tsuda, K.: X-band AlGaN/GaN HEMT with Over 80W Output Power, Compound Semiconductor Integrated Circuit Symposium, CSIC 2006, San Antonio, USA, Nov. 2006

27) 高木一考: $\mathrm{X}$ 帯及び Ku 帯高出力 GaN HEMT の現状，電子情報通 信学会論文誌 C, エレクトロニクス J92-C, 12(2009), pp. 762-769.

28) Fanning, D. M., Witkowski, L. C., Lee, C., Dumka, D. C., Tserng, H. Q., Saunier, P., Gaiewski, W., Piner, E. L., Linthicum, K. J. and Johnson, J. W.: 25 W X-band GaN on Si MMIC, CSMANTECH 2005 Conf. Proc., New Orleans, USA, Apr. 2005

29) Lee, J. W. and Webb, K. J.: A Temperature-dependent Nonlinear Analytic Model for AlGaN-GaN HEMTs on SiC, IEEE Trans. Microwave Theory Tech., 52, 1(2004), pp.2-9.

30) The Space Environment Information System (SPENVIS) Web Page: http://www.spenvis.oma.be/

31) European Space Components Coordination: Total Dose Steady-state Irradiation Test Method, ESCC Basic Specification No. 22900, Mar. 2007. 